\title{
THE PARMAN ECONOMY: POST-AUTHORITARIAN SHIFTS IN THE OFF-BUDGET ECONOMY OF INDONESIA'S SECURITY INSTITUTIONS
}

\section{Jacqui Baker}

Is Jakarta's Polisi Daerah (Polda) Metro Jaya the only regional police station in the world to be glorified with its very own coffee-table book? Released in 2005, the book celebrates renovations to the station that commenced a year earlier. On page ten, the photo of the station from Metro Jaya's main western entry on the Jend. Sudirman motorway takes up the whole page. The photo shows the façade of stern gray cement and polished glass, framed by spouting fountains and date palms. This vision of tropical security chic is Polda Metro Jaya's idea of the proper setting for a professional, civil police force charged with securing newly democratic Indonesia. But in observing the photo, one's eyes are drawn upwards to the right-hand corner, where a squat, gray skyscraper overshadows the station, crowned with these golden initials: GY.

This is Griya Yatra. ${ }^{2}$ Griya Yatra is a conglomerate that has grown substantially since the demise of the New Order. GY owns the slab of land adjacent to Polda Metro

\footnotetext{
${ }^{1}$ The author thanks Joshua Barker, Edward Aspinall, and Indonesia's readers and editors for their critical assessment of drafts of this essay. Earlier versions of this paper also benefited from comments and criticisms from participants at KITLV and the ANU's Indonesia Study Group seminars. The author gratefully acknowledges the John Monash Foundation for its generous support of this research.
} 
Jaya known as the Sudirman Central Business District (SCBD) development, whose central coordinates make it one of the most lucrative pieces of real estate in the capital. In the city, talking about "GY" is often code for talking about its owner, "TO," a peranakan ${ }^{3}$ entrepreneur named Tony Oei. In fact, however, GY is jointly owned by Oei and Alex Guo, an older totok businessman. This pair is said to be like brothers. Although neither comes from Java, together they have forged the conglomerate's identity by baptizing it in Javanese. Griya Yatra means "house of money."

The release of the coffee-table book followed months of media speculation as to the source of the estimated Rp 660 billion needed to pay for the renovations. Metro Jaya had started work on new buildings for Densus 88 (the recently formed anti-terrorist squad) and the mobile brigade (Brimob). There was to be a glossy auditorium, the three-story Al-Kautsar mosque, a five-story car park, new boarding houses for the officers, and refurbished official residences for elite officers. ${ }^{4}$ With no funds allocated from the 2004-05 state budget (APBN, Anggaran Pendapatan dan Belanja Negara), and no supplementary funds proposed to parliament, Indonesians and their legislative representatives wondered where Jakarta's regional police chief (Kapolda Metro Jaya) Inspector General (Irjen pol.) Firman Gan had obtained the money to pay for the station's renovations and improvements.

The head of Polri's (Indonesian National Police, Kepolisian Negara Republik Indonesia) General Oversight Inspectorate (Irawasum, Inspektur Pengawasan Umum), Komjen (Commissioner General) Binarto, tried to address the matter by conducting a review. He concluded that because no public funds had been used, no public funds had been misappropriated. ${ }^{5}$ National Police Chief (Kapolri) General Dai Bachtiar then stepped in with the claim that, although some of the funds had been allocated from the Additional Expenditure Budget (ABT, Anggaran Belanja Tambahan), a statement quickly negated by Komisi III (National Parliamentary Commission III for Law, Human Rights, and Security; it provides parliamentary oversight of Polri), ongoing underfunding of the police by the state meant that Jakarta's regional police chief was forced to rely on community donations, that is, "off-budget" funds. However, Bachtiar was careful to emphasize that such monies were not obtained willy-nilly. Off-budget revenue-raising was ethically bound. Bachtiar insisted that police only accepted donations from patrons who were sincere and wholehearted (ikhlas). If it transpired

\footnotetext{
${ }^{2}$ Pseudonyms have been allocated to Griya Yatra and all of the people and companies associated with it. The military and police businesses named in this article are all real, as are the other companies and their owners cited in this article.

${ }^{3}$ Peranakan are ethnic Chinese Indonesians who are considered to have mixed blood, limited use for ethnic Chinese dialects, and an "assimilated Indonesian-ethnic Chinese" identity. Peranakan are contrasted with totok, who speak an ethnic Chinese dialect, practice everyday Confucianism, and tend to congregate only with other totok. The terms emerged originally during Dutch colonial rule, during peak periods of ethnic Chinese migration, as temporal and relational markers of belonging, though both groups claimed superiority. Contemporary use and identification continues to rest on facial characteristics, religious persuasion, and language use.

${ }^{4}$ Koran Tempo, "Ada Kesalahan Administrasi dalam Pembangunan Gedung Detasemen 88," February 15, 2005, http: / / koran.tempo.co/ konten/2005/02/16/33582/Ada-Kesalahan-Administrasi-dalamPembangunan-Gedung-Detasemen-88, accessed September 6, 2013.

${ }^{5}$ Ibid.
} 
that Metro Jaya had extorted the donations, well then, that would be a disgrace (tercela). ${ }^{6}$

For his own part, the man at the center of the storm, Kapolda Irjen Firman Gani, insisted that the renovations did not rely on external funding. However, he added, if the new buildings were funded through donations, then donors would have signed contracts that verified their charitable intentions. It wasn't as if they were trying to influence or "bribe" the police in any way. ${ }^{7}$ In later comments, Gani blessed those "servants of God who cared about security." He said that Polri's benefactors were men of piety and humility who guarded their anonymity. They weren't the types to seek vulgar public attention by declaring their donations. ${ }^{8}$

Seasoned observers and the press, however, wondered openly whether the renovated facilities had been built within the boundaries of Griya Yatra's SCBD site, insinuating that the land, and, by extension, some of Polda Metro Jay's renovations, had been funded by Oei. ${ }^{9}$ The police's coffee-table book, released after the media storm, is more pointed than Bachtiar and Gani in its acknowledgements of benefactors. It thanks a consortium of ethnic Chinese-owned real estate and construction businesses, including Tony Oei (Griya Yatra), Alex Guo (PT Mandiri Ditpacipta and PT Multi Griya Pratama), Soetjipto Nagaria (Summarecon), Hary Tanusoedibjo (Bimantara group), and Suwarno M Serad (part of Budi Hartono's PT Djarum). Within Jakarta's ethnic Chinese community, these men are envied as laupan, or "big boss."

In 2005, the year the coffee-table book was released, the Supreme Audit Agency (BPK, Badan Pemeriksa Keuangan) raised more questions about Metro Jaya's financing. ${ }^{11}$ The BPK noted significant variations in Polri's financial reports to the agency compared to the documents compiled by Polri's own logistical bureaus (biro logistiks). BPK's audit singled out errors in the Polda Metro Jaya balance sheet, specifically the omission of land worth some Rp 12586.79 billion, building and infrastructure improvements worth Rp 63.83 billion, and a further Rp 38.58 billion in undeclared equipment and vehicles. ${ }^{11}$

The BPK was careful to underscore that the discrepancies in financial reporting were not unique to the Jakarta regional police. In fact, the BPK actually praised Metro Jaya as one of only three regional stations to have ever submitted data to the audit body, or, for that matter, to have undertaken routine financial reporting at all. Nevertheless, the report suggested that fiscal discrepancies and undeclared wealth underpinned Polri's very existence. For instance, 2,700 hectares of land, some 82 percent of the land in Polri's use, is undocumented. ${ }^{12}$ In 2004 alone, a year in which

\footnotetext{
${ }^{6}$ Ibid.

${ }^{7}$ Tempo Interaktif, "Polda Metro Jaya Bangun Gedung Densus 88 Anti-Teror," September 8, 2004, http: / / www.tempo.co/ read/ news/2004/09/08/05747669/Polda-Metro-Jaya-Bangun-Gedung-Densus88-Anti-Teror, accessed September 6, 2013.

8 "Hamba Tuhan di Gedung Anti-terror," Tempo Interaktif, December 27, 2004.

${ }^{9}$ Police analyst, interview with the author, Jakarta, November 17, 2006.

10 "Hasil Pemeriksaan Laporan Keuangan Kepolisian Republik Indonesia Tahun 2004," Badan Pemeriksa Keuangan (audit report), Jakarta, Government of Indonesia, 2005.

${ }^{11}$ Ibid.

${ }^{12}$ This is an area roughly the same size as the borough of Westminster, or inner-city London.
} 
Polri's portion of the national budget was some Rp 7.9 trillion (as shown in Table 2), Polri had generated undocumented assets from grants and donations to the tune of $\mathrm{Rp}$ 163.13 billion, or about 2 percent of its budget. BPK stumbled on these figures because of discrepancies in the data submitted by different departments of the police force. This shows how dependent the state auditor is on institutional reporting to identify discrepancies. In fact, these figures represented only the tip of a monstrous fiscal iceberg, a mostly invisible off-budget economy that sustains the national police force. ${ }^{13}$

In 1999, in one of the first steps of democratic security sector reform, the Indonesian National Police were separated from the Indonesian National Armed Forces (TNI, Tentara Nasional Indonesia). This institutional split reflected a major shift in the traditional balance of authority between military and police. Under the New Order, the military, principally the army, usurped the police's functional role as a provider of security and defender of law and order. With the fall of the New Order, the police's authority over law and security has been reinstated. However, democratic reform of the Indonesian military has been mixed. The TNI continues to wield political power, and the army continues to have a presence in everyday security activities, although now it is secondary to Polri.

One important arena for military power during Suharto's rule was the considerable economic stake TNI officers had in local economies, which provided a substantial portion of their budget and income. Such undocumented fund-raising was justified by resource deficiencies. Throughout the New Order and into the democratic era, the police and the military have argued that their budgetary allocations do not reflect their actual workload. This ongoing situation has spawned what is called the off-budget economy: a vast, convoluted range of revenue-raising practices, both illicit and licit, that funnel unaccountable sums of money to the security institutions.

This article has two aims. First, I will examine the police's off-budget economy during and after the New Order. Current literature on off-budget revenue-raising by the military incorrectly subsumes police within the ABRI (Angkatan Bersenjata Republik Indonesia, Indonesian Armed Forces, before the reinstatement of the TNI) complex. Not only did the police experience vastly different revenue-raising opportunities under ABRI relative to the military, but the independence of the police institution, the rise in its authority, and Polri's annual complaint that treasury funds do not adequately meet institutional expenses, opens up a considerable gap in the literature about police revenue-raising in the democratic period. I demonstrate how willful institutional and fiscal maladministration culminate in overwhelming resource deficiencies that legitimize and sustain the Indonesian police's off-budget economy. This contradicts conventional arguments that the off-budget economy is born of the poverty of the developing Indonesian state.

\footnotetext{
${ }^{13}$ Indeed, I would venture that because these figures rely on the auditor's comparison between the sloppy, permissive inventories of wealth compiled by the MABES (Markas Besar, headquarters) logistics bureau and those sent to a hostile BPK, they are staggeringly understated and only haphazardly accurate. Not only does the BPK have no access to the financial reports of most of the provincial, district, and subdistrict stations, but what reports it does have are likely falsified. Moreover, the BPK cannot examine the accounts of individual officers, many of whom act as fiduciaries for donations later distributed to Polri in the form of operational funds or infrastructure.
} 
Secondly, I highlight the political economy of off-budget financing by spotlighting the considerable fiscal contribution that ethnic-Chinese capitalists have made to the off-budget economy of the military and the police. Here, I look at two types of structured alliances: joint enterprises between military generals and ethnic Chinese capitalists, and "friendships" between police generals and ethnic Chinese capitalists in the democratic period. These friendships are known as "parman," an acronym for partisipasi teman, or the "participation of a friend." What I call the "parman economy," the title of this article, is the hidden (secretive, invisible) flow of gifts, capital, and other commodities from ethnic Chinese capitalists that is channeled to police officers. Through the politics of land ownership in Jakarta's SCBD, I show how this pattern of rising police power and military withdrawal (short of retreat) that characterizes security sector reform in the democratic period, is also evident in the illicit world of off-budget financing.

\section{Capital in the Off-budget Economy}

Dana non-budjeter, or off-budget revenue, as an illicit source of finance to treasury funds, has an established history in the study of the Indonesian state. ${ }^{14}$ Here, the offbudget economy should be differentiated from the kind of independent, institutional revenue-raising that, since the 1980s, has become a hallmark of modern, neoliberal governance. ${ }^{15}$ In Indonesia, the state has encouraged and profited from institutional off-budget income-generation systems of varying legality, sophistication, and transparency, justified by the central assumption that APBN funds do not cover the "real" costs of expenditure on police and military forces. Meanwhile, little information is available publicly on the forms that off-budget financing takes. Off-budget revenues are not declared, audited, or returned to the state treasury, as per Indonesian laws on non-tax revenue. ${ }^{16}$ The absence of transparency allows the off-budget finances to be spent in a discretionary manner by institutional powerbrokers. Moreover, as long as state institutions are able to solicit monies externally, they are fiscally less dependent

\footnotetext{
${ }^{14}$ See Leo Suryadinata, The Culture of the Ethnic Chinese Minority in Indonesia (Singapore: Times Books, 1997); William Ascher, "From Oil to Timber: The Political Economy of Off-Budget Development Financing in Indonesia," Indonesia 65 (April 1998): 37-62, http:/ / cip.cornell.edu/ DPubS?service=UI\&version=1.0 \&verb=Display\&handle=seap.indo/1106953919, accessed August 7, 2013; Ross McLeod, "Inadequate Budgets and Salaries as Instruments for Institutionalizing Public Sector Corruption in Indonesia," Southeast Asia Research 16,2 (2008): 199-223; Marcus Mietzner, "Soldiers, Parties, and Bureaucrats: Illicit Fund Raising in Contemporary Indonesia," Southeast Asia Research 16,2 (2008): 225-54; and Lex Rieffel and Karaniya Dharmasaputra, Tata Kelola Yayasan-Pemerintah: Ujian bagi Reformasi Birokrasi (Washington, DC: Brookings Freedom Institute, December 31, 2008), http: / / www.docstoc.com/ docs / 25724561/ Tata-KelolaYayasan-Pemerintah-Ujian-bagi-Reformasi-Birokrasi, accessed August 8, 2013.

${ }^{15}$ David Harvey, "From Managerialism to Entrepreneurialism: The Transformation in Urban Governance in Late Capitalism," Geografiska Annaler 71B (1989): 3-17.

${ }^{16}$ Ross McLeod, "Public Sector Accounting Reform at the Local Government Level in Indonesia," Financial Accountability and Management, forthcoming; Lesley McCulloch, "Trifungsi: The Role of the Indonesian Military in Business," in The Military as an Economic Actor, ed. Jörn Brömmelhörster and Wolf-Christian Paes (London: Palgrave McMillan, 2003), pp. 94-123.
} 
on the state. ${ }^{17}$ This compromises the very coherence and structure of the state as we know it. ${ }^{18}$

Although off-budget financing is widespread throughout the Indonesian state, these practices have largely been associated with the Indonesian military. ${ }^{19}$ The military's off-budget economy traverses the history of the Indonesian state. During the revolutionary struggle against the Dutch, a localized system of tithing and taxation was established to fuel the military effort. ${ }^{2(1)}$ These revenues were supplemented by informal activities such as smuggling, and the illicit trafficking of copra, rubber, and opium was also an important means by which the guerrilla war was financed. In the late 1950s and early 1960s, leading up to the New Order, Nasution's vision of an expanded social and political role for the military (dwifungsi) transformed and expanded the formalized elements of the military's off-budget economy into a substantial commercial empire, as generals acquired prominent roles in nationalized Dutch companies. Military businesses peaked under the New Order, as ABRI leveraged its political weight to establish a large complex of joint enterprises, cooperatives, and foundations, any of which were not viable without political support, and all of which collapsed with the late-1990s financial crisis. The post-authoritarian period has been marked by changes to the laws on state fund-raising, and pressure on the government to take over military businesses and force TNI's dependence on the state budget. However, this proposed reform has been met with significant political foot-dragging. ${ }^{21}$

Scholars have remarked that a major problem in researching the military's offbudget economy has been the dearth of data that would enable quantitative estimations of the size of the off-budget economy and the depth of the budgetary shortfall. ${ }^{22}$ Under the New Order, it was suggested that the military acquired 70 percent of its revenue from off-budget sources, an often-cited figure that has proved impossible for scholars to verify with any certainty. ${ }^{23}$ With the reforms of the postauthoritarian era, former defense minister Juwono Sudarsono has estimated this figure to be around 30 percent. ${ }^{24}$ Yet contrary to this estimate, Mietzner suggests that the revenues of formal military businesses do not exceed US\$20 million. This means that in

\footnotetext{
${ }^{17}$ Mietzner, "Soldiers, Parties, and Bureaucrats"; Jörn Brömmelhörster and Wolf-Christian Paes, "Soldiers in Business: An Introduction," in The Military as an Economic Actor, ed. Jörn Brommelhörster and WolfChristian Paes (London: Palgrave McMillan, 2003), pp. 1-17.

${ }^{18}$ Jacqui Baker, "The Rhizome State: Illicit State Financing and the Fiscal Sociology of the Southeast Asian State," paper presented at EUROSEAS, Lisbon, Portugal, July 3, 2013.

${ }^{19}$ Mietzner, "Soldiers, Parties, and Bureaucrats."

${ }^{20}$ Salim Said, The Genesis of Power: General Sudirman and the Indonesian Military in Politics, 1945-49 (Singapore: ISEAS, 1991).

${ }^{21}$ Human Rights Watch, "Too High a Price: The Human Rights Cost of the Indonesian Military's Economic Activities," Human Rights Watch 18,5C (2006). See also Mietzner, "Soldiers, Parties, and Bureaucrats."

22 See Mietzner, "Soldiers, Parties, and Bureaucrats"; Human Rights Watch, "Too High a Price"; and Lex Rieffel and Jaleswari Pramodhawardani, Out of Business and On Budget: The Challenge of Military Financing in Indonesia (Washington, DC: Brookings Freedom Institute, 2003).

${ }^{23}$ Ibid.

${ }^{24}$ Mietzner, "Soldiers, Parties, and Bureaucrats," p. 236.
} 
2008 , the TNI's revenue from formal businesses made up only 0.5 percent of the defense budget. ${ }^{25}$

Material presented in the latter part of this article on Polri's off-budget economy suggests that questions concerning budgetary shortfall and the surrogate role of offbudget financing are redundant and represent an erroneous attempt to analyze the offbudget economy with the rational, normative lens that scholarship applies to formal budgeting and financing systems. These assumptions comply with the generals' refrain that off-budget revenues are directed towards the operational costs of the institution. Off-budget financing should not be understood as a parallel revenue system, subject to the same norms of accountability, transparency, priority, and distribution that govern the use of treasury funds. It's not that the off-budget economy is like a "normal," rationalized financing system, except that it is illicit. Spending on "institutional costs" is part of but not the principal way in which off-budget revenues are exhausted. Rather, the off-budget economy needs to be seen as the corresponding system of tribute, accumulation, and reward that services the political life of the institution that determines promotions, rotations, and the division of authority. Though subterranean and complex, the politics of Polri is the single greatest concern of an ambitious officer. Given this situation, the off-budget economy operates according to multiple, often contradictory logics including reciprocity, reward, seniority, entrepreneurship, kinship, charismatic power, and the "ethics" of personal wealth. ${ }^{26}$ Officers may negotiate, subvert, or transgress these logics outright, but they are nonetheless important to the off-budget economy's workings and endurance.

Typologies of military business tend to be largely organized by gradations of legality, rather than value, organizational structure, or governmental tier, all of which vary greatly. Off-budget financing of the military is divided into four main categories:

1) Legitimate companies overseen by military foundations (yayasan) or cooperatives (kooperasi) operating across a vast range of economic sectors, including transportation, manufacturing, natural resources, and agribusiness. This category includes joint enterprises with foreign companies, Suharto family members, or ethnic Chinese elites.

2) Gray-area or informal business enterprises, such as commercializing state assets or authorities (e.g., renting military land; selling used government property); requiring regular (but nonetheless dubious) security payments of large private companies, such as Freeport; or cultivating special relationships with state owned enterprises, such as Pertamina (Perusahaan Energi Indonesia, formerly Perusahaan Pertambangan Minyak dan Gas Bumi Negara, State Oil and Natural Gas Mining Company), Bulog (Badan Urusan Logistik, Indonesian Bureau of Logistics), or, formerly, Bidakari.

3) Illegal business activities in the vice economies of gambling or prostitution, or providing fee-based protection to illegal logging and smuggling rackets.

\footnotetext{
${ }^{25}$ Ibid.

${ }^{26}$ Jacqui Baker, "The Devil's Money is Eaten by His Lesser Demons: The Ethics of Illicit Police Financing in Indonesia" (forthcoming).
} 
4) Blatant corruption, including procurement markups, misusing foundation or cooperative funds, or enacting and enforcing illegal levies and fees.

This article focuses narrowly on a subset of the first type of military financing: joint enterprises with ethnic Chinese entrepreneurs. In fact, most military-run companies have operated under shared ownership, principally with ethnic Chinese entrepreneurs. ${ }^{27}$ There are two interrelated reasons for this, rooted in the historical structures of discrimination and political segregation that have marked ethnic Chinese citizenship from the time of the early colonial regime. Firstly, ethnic Chinese business groups dominate medium and large-scale corporate capital and own the majority of private capital. Secondly, decades of periodic, state-sanctioned, anti-Chinese sentiment have ensured that ethnic Chinese are security-poor despite their being capital-rich. ${ }^{28}$ To "secure" persons, property, and livelihoods, ethnic Chinese under the New Order were encouraged to seek out alliances with indigenous politico-bureaucrats who controlled the system of political patronage. Military officers, as important figures of coercive and political power, provided an umbrella of protection for ethnic Chinese property, assets, and livelihoods in exchange for material benefits for officers and the military institution. Colloquially, this relationship is known as "cukongism." ${ }^{29}$

Cukongism is often erroneously compared to a patron-client relationship, however, this kind of power dynamic does not fit with the overall position of ethnic Chinese within Indonesian state and society. ${ }^{30}$ There is no doubting that ethnic Chinese capitalists benefited substantially from their alliances with the state, but few have interrogated the stakes that would have been involved if ethnic Chinese had refused such partnerships. Mutually beneficial exchanges were often underlined by the threat of coercion. ${ }^{31}$ Christian Chua argues that these symbiotic relationships contributed to the development of a complex "oligarchy" consisting of political powerbrokers and capital-rich ethnic Chinese who dominated the New Order and its signature style of predatory capitalism. ${ }^{32}$ Chua contends that the fall of Suharto's military regime and the processes of democratization, decentralization, and deregulation that have marked the post-authoritarian period have effectively emancipated ethnic Chinese business from the politico-bureaucratic class. He predicts that democracy will encourage the unfettered rise of capital. The implications of this article contradict and complicate Chua's argument. The "parman economy" I describe suggests that, despite their newfound "liberty," ethnic Chinese capitalists continue to seek out potent protective relationships with the dominant coercive body. The reasons for this are complex and

\footnotetext{
${ }^{27}$ Richard Robison, Indonesia: The Rise of Capital (Jakarta: Equinox Publishing, 2009).

${ }^{28}$ Jemma Purdey, Anti-Chinese Violence in Indonesia (Honolulu, HI: University of Hawaii Press, 2006).

${ }^{29}$ Leo Suryadinata, The Culture of the Ethnic Chinese Minority in Indonesia. Suryadinata explains that the word cukong is Hokkien for "master" or "boss," and the term has long been used to describe aggressive business entrepreneurs who often acted as informal leaders for certain parts of the ethnic Chinese community. Only in the New Order did cukongism come to represent a set of relations in which ethnic Chinese businessmen provided capital and directional support to the pribumi political and military elite in exchange for economic, political, and security privileges, to the detriment of the public interest

${ }^{30}$ Purdey, Anti-Chinese Violence in Indonesia, p. 21.

${ }^{31}$ Ascher, "From Oil to Timber," pp. 54-60.

${ }^{32}$ Christian Chua, Chinese Big Business in Indonesia: The State of Capital (London and New York, NY: Routledge, 2008).
} 
beyond the scope of this article. Interview data presented here, however, suggests two possible areas of inquiry. Firstly, that outright coercion has played an underappreciated role in the forming of these alliances, and, secondly, that history, memory, and belief play a significant role in these exchanges, and interpretations acknowledging such forces trump narrow political-economy analyses of the behavior of capital.

\section{Militarized Business Alliances in the New Order}

Officially, Polda Metro Jaya is adjacent to Lot \#1 of the forty-two hectares of prime real estate that make up the Sudirman Central Business District. Zoned between three of the city's main arteries-Jalan Sudirman, Jalan Rasuna Said, and Jalan Gatot Subroto-the area is marketed as "Jakarta"s Golden Triangle." Alongside Metro Jaya's recent property expansion, the Golden Triangle is home to the Jakarta Stock Exchange, the World Bank offices, USAID, Tan Kian's Ritz Carlton, a series of exclusive serviced apartments built by PT Raya Sedayu (another property group jointly owned by Oei and Guo), a golf range, an auto and electronics mall, a bagel shop, and Pacific Place, another of Jakarta's lifestyle malls. In 2020, SCBD's landscape will be augmented by the Signature Tower, the world's fifth tallest building.

When viewed from Jalan Sudirman, the Griya Yatra building (with its flaxen initials winking over the city) appears to be staked before this hoard of skyscrapers like a picket in turf. Griya Yatra is the mother company to PT Danayasa Griyatama, the holding company that owns, develops, and manages the upscale properties that proliferate in SCBD's golden triangle. ${ }^{33}$ PT Danayasa Griyatama is also owned in part by Alex Guo, owner of conglomerate Raya Sedayu Group. In 1990, PT Danayasa Griyatama surprised financial observers by acquiring a majority share in a state-owned company (BUMN, Badan Usaha Milik Negara) called PT JT Jakarta International Hotel Development (PT JIHD). With funds from PT JIHD, PT Danayasa Griyatama proceeded to pay Rp 7.5 trillion in 1991 for the SCBD site, then a "fantastical sum" for real estate even in central Jakarta. ${ }^{34}$ In 1999, Human Rights Watch valued the property at an estimated three billion US dollars. ${ }^{35}$ Previously, neither Oei nor Guo had ever managed a property deal that came even close to that sum. ${ }^{36}$

The scale and grandeur of the SCBD project was even more surprising given PT JIHD's middling property portfolio, which then consisted of a handful of luxury, if outdated, hotels in Jakarta and Kuta. How could such a pedestrian property firm plunge into the city's biggest-ever real estate deals? The answer lay in the company's origins. PT JIHD was, in fact, one of dozens of subsidiaries grouped under PT Tri

\footnotetext{
${ }^{33}$ The name of the company has been changed for publication. Below this company are nineteen other subsidiaries involved in tourism, luxury housing, retail, real estate, trading, and construction. Most of these companies have a stake in the SCBD.

${ }^{34}$ Dwitri Waluyo, Asrori S. Karni, and Rohmat Haryadi, “Bisnis Taipan Beragam Stigma,” Gatra, March 17, 2003, http: / / www.gatra.com/2003-03-17/versi_cetak.php?id=26297, accessed August 7, 2013.

${ }^{35}$ Human Rights Watch, "Too High a Price."

${ }^{36}$ Coincidentally, in the year of the SCBD purchase, Guo's Raya Sedayu group completed its first big construction project, the Harco Mangga Dua complex in Central Jakarta.
} 
Usaha Bakti (Truba), a holding company of Yayasan Kartika Eka Paksi (YKEP, Kartika Eka Paksi Foundation), which during the New Order was the Indonesian army's largest foundation. Established in 1972, YKEP developed a vast investment portfolio that spanned forestry, manufacturing, mining, transportation, university education, and, later, as just described, the diamond in its tiara that was SCBD. Thus, PT JIHD and PT Danayasa Griyatama's interest in the Golden Triangle resulted from a marriage of military capital and ethnic Chinese business acumen. The land in the SCBD allegedly "gifted" to Polda Metro Jaya in 2004, was, in 1991, an emblem of the alliance between Jakarta's new ethnic Chinese tycoons and the army under late New Order capitalism.

The deepening relationship between the foundation and the conglomerate had been affirmed by the earlier appointment of Siliwangi officer Lieutenant General TB Silalahi to First Commissioner of PT Danayasa Griyatama and Bank Griya Yatra. ${ }^{37}$ Silalahi was the first in a procession of senior military figures to hold commissioner status in the GY empire. Officially, the military commissioners on the GY board were there to monitor YKEP's stake in the partnership, but the effect of their association was to demonstrate that the company enjoyed military protection from the highest levels, thus catapulting forward the company's commercial dealings.

By creating such military-commercial alliances, YKEP and Griya Yatra were merely aping the historical pattern of revenue-raising established by Suharto himself. In 1957, as head of Central Java's Diponogoro military command, Suharto had partnered with Semarang's large ethnic-Chinese trader class to establish business interests in primary commodities and shopping, generating revenue that could then be channeled through a host of military foundations and cooperatives. Although the commercial activities were, in principle, for "troop welfare," senior staff were rewarded with placements in state and private enterprises that yielded them, personally, a share of the profits. Suharto was rotated from the Diponogoro post in 1959 on accusations of corruption. As president, however, Suharto instituted this selfsame model of joint partnerships to generate wealth for the indigenous political and security elite. As the president's greed accelerated, so did the fortunes of choice ethnic Chinese capitalists, most notably his old Semarang crony Liem Sioe Liong (later reported to be the richest man in Indonesia). The New Order also saw the rise of other laupan, including Mochtar Riady, Sjamsul Nursalim, Prajogo Pangestu, Sukanto Tanoto, Eka Tjipta Widjaya, and Rachman Halim. Oei and Guo's emergence in the final years of New Order capitalism added two new big bosses to this list.

However, the economic landscape was changing and with it the inner dynamics of the oligarchy. By 1991, the year of the SCBD purchase, liberalization and selective deregulation were profiting both ethnic Chinese and politico-bureaucrats. The capital base of the politico-bureaucrats had fattened considerably, decreasing their reliance on ethnic Chinese big business. ${ }^{38}$ Similarly, ethnic Chinese capitalists were edging into international markets and increasing their autonomy from the state. Reforms to the

\footnotetext{
${ }^{37}$ One of the first ventures of the Oei-Guo-army triad was the takeover of Yayasan Siliwangi's Bank Propelat. By 1989, Bank Propelat was Rp 600 billion (US\$67 million) in the red, thanks to corrupt lending practices and bad debts. Oei-Guo took on the bank, renamed it Bank Griya Yatra, and by 1992 Oei-Guo enjoyed a majority share. Yayasan Siliwangi had only a 40 percent stake in Bank Griya Yatra. Bank Griya Yatra is today one of the top commercial banking firms in the country.

${ }^{38}$ Chua, Chinese Big Business in Indonesia, p. 55.
} 
banking sector saw a glut of banks open, as ethnic Chinese conglomerates sought to increase their liquidity. With inflation and interest rates equally paired, a property boom ensued. Up to 25 percent of all lending during this time was directed at largescale property projects, the largest of which was SCBD. ${ }^{39}$ Chua argues that the longterm effect of these neoliberal reforms, coupled with the collapse of the New Order, would radically change the power balance between ethnic Chinese big business and state elites. ${ }^{40}$ Oei and Guo's sudden break into the top league of Jakarta laupan represented, in fact, one of the final alliances between ethnic Chinese capitalists and the security elite.

Joint enterprises were at the crux of the YKEP empire. Although it was YKEP'S most expensive project, the SCBD initiative was only one of twenty-six other joint ventures under its holding company, PT Truba. At its height, PT Truba oversaw thirteen affiliated firms and twenty-six joint ventures, worth a total of Rp 314 billion. ${ }^{41}$ Partners included Suharto cronies and ethnic Chinese businesspeople. PT Truba's 51 percent share in International Timber Corp was shared with Bob Hasan (35 percent) and Suharto's third son, Bambang Trihatmodjo (14 percent). Hasan and Suharto's youngest son, Tommy, also partnered with PT Truba through Sempati Air and Truba's timber interests in Kalimantan, jointly held with ethnic Chinese entrepreneur Jos Soetomo, through PT Sumber Mas. In 1996, PT Truba was 140th on the list of Indonesia's biggest conglomerates. ${ }^{42}$

Joint enterprises masked the fact that, on their own, military businesses tended to be under-capitalized, ill-structured, and poorly managed. Ethnic Chinese entrepreneurs offered the military a way of turning "political resources into real profits." ${ }^{43}$ Robison shows how the military used its political clout to lever logging and mining concessions with very small sums of investment, around $\mathrm{Rp} \mathrm{2-3}$ million. Production would languish until the military negotiated joint ventures with ethnic Chinese businesses that supplied the project with capital and the expertise to manage it. Robison has proposed that, in fact, the military's investment in the partnership was the very concession itself. Military officers provided only the security and prestige of partnership in return for a cut of profits. This helped maintain a military-enterprise system that would have collapsed far earlier than it eventually did had it been entirely self-financed and -managed.

With capital steering military commerce, it's unsurprising that military businesses mimicked the strategies and structures of ethnic-Chinese-owned conglomerates: random diversification around a series of vertically integrated cartels that supplied a

\footnotetext{
${ }^{39}$ Joe Studwell, Asian Godfathers (London: Profile Books, 2007). Many of these projects involved the construction of the kind of large-scale, gated residential developments that have transformed Jakarta's urban landscape, intensified spatial segregation, and changed the face of traditional security arrangements.

${ }^{41}$ Rieffel and Pramodhawardani, Out of Business, pp. 30-31. The profits of YKEP brought in around Rp 3050 billion (US\$300,000-500,000]) per year. Otto Syamsuddin Ishak, "The Sociology of Military Business in Indonesia," in Practices of Military Business: Experiences from Indonesia, Burma, Philippines, and South Korea, ed. Mochtar Nurhasim (Jakarta: The Ridep Institute and Friedrich Ebert Stiftung, 2005)

42 Tom McCawley, "Bullets and Bottomlines," Asiaweek.com, undated, http://edition.cnn.com/ ASIANOW/asiaweek/99/0205/biz1.html Accessed September 6, 2013

${ }^{43}$ Robison, Indonesia: The Rise of Capital, p. 256
} 
core cash flow. ${ }^{44}$ In the signature style of most ethnic Chinese conglomerates, YKEP raised enough capital to allow it to dominate entire production chains. ${ }^{45}$ Vertical integration allowed YKEP to determine how much profit and loss showed up on the books, diverting funds so that companies appeared less wealthy than they actually were or obscuring the profits being siphoned into officers' pockets. With "too much easy cash and too much easy credit," ${ }^{46}$ YKEP diversified in order to establish more monopolies in other sectors of the economy rather than work at building dedicated, competitive companies with maximized earnings. Joe Studwell observes that this is a classic symptom of "a license-based operating environment in which competition is limited by the state and so any new business opportunity is to be grabbed at." ${ }^{47}$ But if we examine YKEP strategy through a slightly different lens, one that does not focus exclusively on economic factors, we develop a picture that is more revealing. This was a kind of predatory capitalism driven by a grinding anxiety about the temporal and political limits of empire-building. Vertical integration and random diversification evidence the plunder mentality that emerges in a precocious patrimonial system.

The nationalization of industry in 1957 saw military officers take on important roles as advisors, commissioners, and managers of state companies. With the expansion of joint enterprises involving the army and ethnic Chinese capital, senior and retired army officers filtered into cushy positions within the wider web of ethnic-Chineseowned conglomerates. From here, military generals performed a largely theatrical role. For ethnic Chinese entrepreneurs, demonstrating beking (backing, support) through close association with the military was critical to effecting the security that businesspeople craved. A military official appointed to the board of directors suggested to circling extortionists (usually rival generals) and business competitors alike that "this guy's not to be trifled with. $\mathrm{He}^{\prime}$ s got a general." ${ }^{48}$ Ethnic Chinese spoke to me repeatedly of the need, not to align with or engage, but specifically to "tempel" (to plaster or affix) a general to their conglomerates, as if the officer were a potent talisman. On the part of the generals-turned-commissioner, it was increasingly unclear whether officers were there to represent military business interests or increase their personal wealth.

\section{Sibling Rivalry}

In 1972, the year YKEP was created, the navy and air force also established their own vehicles for off-budget fundraising. Well known among them was the navy's Yayasan Bhumyamca, which had around thirty-two companies in 2000, and the air force's Yayasan Adhi Upaya, whose ten companies were invested in construction, property, airlines, and pharmaceuticals. ${ }^{49}$ The air force's PT Angkasa Pura also held a major stake in the commercial and state airline industry.

\footnotetext{
${ }^{44}$ Studwell, Asian Godfathers.

${ }^{45}$ Retired Police General, interview with the author, Jakarta, April 11, 2007.

${ }^{46}$ Studwell, Asian Godfathers, p. 82

${ }^{47}$ Ibid.

${ }^{48}$ Interview with the author, Jakarta, April 6, 2007.

${ }^{49}$ Human Rights Watch, “Too High a Price," pp. 35-36
} 
Table 1: Subsidiaries of Yayasan Brata Bhakti ${ }^{50}$

\begin{tabular}{|c|c|c|c|}
\hline \begin{tabular}{|l|} 
Yayasan Brata \\
Bhakti (Brata \\
Bhakti Foundation) \\
\end{tabular} & Ownership & $\begin{array}{l}\text { Profit } \\
2007\end{array}$ & $\begin{array}{l}\text { Dividends } \\
2007\end{array}$ \\
\hline Bara Induk & $\begin{array}{l}\text { YBB owns 20\% share. PT used to have } \\
\text { HPH (hak pengusahaan hutan, forest } \\
\text { concession rights) for approx. 180,000 } \\
\text { hectares in Serang (Maluku), Riau, and } \\
\text { North Sumatra. Accused of illegal log- } \\
\text { ging in national forests in Riau and North } \\
\text { Sumatra. HPH not renewed in } 2003 \text {. }\end{array}$ & $\mathrm{N} / \mathrm{A}$ & $\begin{array}{l}\text { Rp } 700 \text { million } \\
\text { (US } \$ 79,000)\end{array}$ \\
\hline Tana Trisna & $\begin{array}{l}90 \% \text { share. Industrial feeders, cold } \\
\text { storage, Polri supplies, shrimp, timber, } \\
\text { chemical supplies. }\end{array}$ & $\mathrm{N} / \mathrm{A}$ & N/A \\
\hline Panca Trisna & $\begin{array}{l}90 \% \text { share. General trading and } \\
\text { supplier to Polri }\end{array}$ & $\begin{array}{c}\text { Rp } 1 \text { billion } \\
\text { (US } \$ 112 \text { million) } \\
\end{array}$ & $\begin{array}{l}\text { Rp } 500 \text { million } \\
\text { (US } \$ 56,000)\end{array}$ \\
\hline $\begin{array}{l}\text { Braja Tama } \\
\text { (Karangsetra) }\end{array}$ & $\begin{array}{l}90 \% \text { share. HPH in West Kalimantan; } \\
\text { hotel and swimming pool in Bandung. }\end{array}$ & $\begin{array}{c}\operatorname{Rp} 1 \text { billion } \\
\text { (US } \$ 112 \text { million) }\end{array}$ & $\begin{array}{l}\text { Rp } 480 \text { million } \\
\text { (US } \$ 56,000)\end{array}$ \\
\hline Braja Tara & $\begin{array}{l}90 \% \text { share. General trade and explosive } \\
\text { equipment }\end{array}$ & $\begin{array}{l}\text { Rp } 20 \text { million } \\
(\mathrm{US} \$ 2,300)\end{array}$ & $\mathrm{N} / \mathrm{A}$ \\
\hline $\begin{array}{l}\text { Brata Sarana } \\
\text { Bhakti }\end{array}$ & $90 \%$ share. Construction. & N/A & N/A \\
\hline $\begin{array}{l}\text { Asuransi Bhakti } \\
\text { Bayangkara }\end{array}$ & $\begin{array}{l}\text { 51\% share. Insurance company. Polri's } \\
\text { traffic directorate illegally extracts a Rp } \\
30,000 \text { levy for insurance from PT ABB } \\
\text { for driver license applicants. }\end{array}$ & $\begin{array}{l}\mathrm{Rp} 2.1 \text { billion } \\
\text { (US\$235 million) }\end{array}$ & $\begin{array}{l}\text { Rp } 600 \text { million } \\
\text { (US } \$ 67,000)\end{array}$ \\
\hline $\begin{array}{l}\text { Sapta Pirsa } \\
\text { Mandiri }\end{array}$ & $\begin{array}{l}35 \% \text { share. Loss adjustment and } \\
\text { surveying. }\end{array}$ & N/A & N/A \\
\hline $\begin{array}{l}\text { Sekom Bayangkara } \\
(2001)\end{array}$ & $\begin{array}{l}35 \% \text { share. Subsidiary of Japanese } \\
\text { company, Secom Ltd Security guards } \\
\text { and equipment. In } 2009 \text {, the company's } \\
\text { estimated value was up by } 15 \% \text {. }\end{array}$ & $\begin{array}{l}\text { Rp } 1.25 \text { billion } \\
\text { (US } \$ 140 \text { million) }\end{array}$ & $\begin{array}{l}\text { Rp } 400 \text { million } \\
\text { (US } \$ 45,000)\end{array}$ \\
\hline $\begin{array}{l}\text { Citra Graha Lestari } \\
\text { Persada (1999) }\end{array}$ & $\begin{array}{l}55 \% \text { share. Storage and parking at } \\
\text { Samsat, Dan Mogot. }\end{array}$ & $\begin{array}{l}\text { Rp } 130 \text { million } \\
\text { (US } \$ 15,000)\end{array}$ & $\begin{array}{l}\text { Rp } 40 \text { million } \\
\text { (US } \$ 4,500)\end{array}$ \\
\hline $\begin{array}{l}\text { Bimantara } \\
\text { Building }\end{array}$ & $\begin{array}{l}\text { In 2007, owned by YBB. Now appears } \\
\text { to be owned by Hari Tanoe, through } \\
\text { PT Bimantara Citra. }\end{array}$ & $\begin{array}{c}\mathrm{US} \$ 20,000 \text { per } \\
\text { year donation } \\
\text { (sumbangan tetap) }\end{array}$ & $\begin{array}{l}\text { Rp } 73 \text { million } \\
\text { (US } \$ 8,200)\end{array}$ \\
\hline
\end{tabular}

As the youngest sibling of ABRI, Mabes Polri's efforts to intercept state and private commerce were channeled mainly through Yayasan Brata Bhakti (YBB). Established in 1952, YBB is, ironically, the oldest of all the foundations of the coercive apparatus.

\footnotetext{
${ }^{50}$ Yayasan Brata Bhakti, interview with the author, Jakarta, A pril 24, 2008. I am indebted to Karaniya Dharm Asaputra for his guidance during this interview. My figures have been checked against his in Rieffel and Dharmasaputra, Tata Kelola Yayasan, p. 40.
} 
Today, YBB oversees around ten trade, insurance, and forestry companies (see Table 1, above). ${ }^{51}$

Now regulated by the Foundation Laws of 2004, YBB no longer raises capital through partnership with the private sector, although its activities continue to be heavily controlled by the Kapolri, Wakapolri (Wakil Kapolri, Deputy National Police Chief), and Irwasum. Police officials at YBB argue that the foundation no longer operates as a "mask" (topeng) for Polri's business interests and insist that most of the companies under its auspices are idle or unprofitable. ${ }^{52}$

YBB's commercial activity shows that police companies by and large failed to attract the level of liquidity, diversification, and joint entrepreneurship of similar military organizations during the New Order. Most of the contracts Polri entertained, like transportation for Bulog or migrant workers, were just a sliver of a much more lucrative industry muscled out of the state economy. Polri failed to piggyback on ethnic Chinese capital to build vertically integrated cartels in the style of YKEP.

Similarly, by the time Suharto fell, active and retired Polri officers were absent from the executive boards of ethnic Chinese conglomerates, suggesting that here, too, the most powerful Polri staff still lacked the clout needed to benefit from the richest prizes of the security sector's off-budget economy. Since Polri was effectively the youngest sibling in a military state, partnering with the national police offered Chinese capitalists minimal protective power and limited fiscal return. What good was a police general on the board when he could be so easily trumped by an army general? Polri, in the New Order, was a poor man's talisman. Democratization was to change all of this.

\section{Polri's Fiscal Organization}

Following the dissolution of ABRI and establishment of Polri's independence in 1999, the police regained control over domestic security and law enforcement. More importantly, from Polri's perspective, the generals had their institution back. For the first time in thirty-two years, Polri had complete authority over its own systems of education, recruitment and promotion, and budgeting. The independence of Polri was marked by a pledge of institutional reform by Polri's top brass. ${ }^{53}$ However, the pattern of political compromise and alliance-building distinctive to Indonesia's transition from authoritarian rule meant that Polri emerged under the direct supervision of the president, unencumbered by other bureaucratic and public oversight measures. This

\footnotetext{
${ }^{51}$ Yayasan Brata Bhakti, interview with the author, Jakarta, A pril 24, 2008.

52 Ibid. Comparatively, however, YBB's self-stated income appears to be quite buoyant. In a recent comparison of yayasan managed by state departments, YBB is second only to Bank Indonesia (the central bank) in takings. So great is Yayasan Kesejahteraan Karyawan Bank Indonesia's (YKKBI, or the Prosperity Foundation of Employees of Bank Indonesia) Rp 5.3 trillion (US\$590 million) yearly income that the researchers were unable to include it on the graph. Rieffel and Dharmasaputra, Tata Kelola Yayasan, p. 41.

53 "Reformasi Menuju Polri yang Professional," Markas Besar Kepolisian Republik Indonesia, Jakarta, 1999 (government pamphlet).
} 
presented Polri's generals with the unique power to determine the pace and scope of their own institutional reform. ${ }^{54}$

Budgetary authority had long been a source of friction within ABRI. ABRI assumed control of Polri's budgetary processes sometime after 1968, and with that the police's top brass found themselves shut out of fiscal decision-making processes. As the fourth brother of the security apparatus, Polri had been subject to the same kind of fraternal bullying, random plunder, and fiscal-hand-me-downs that characterize sibling relations everywhere. Polri was last on the receiving end of everything, from treasury funds to off-budget revenue-raising opportunities, causing resentment among its top leadership. Consequently, the restoration of Polri's budgetary authority and the power to calculate and annually request Polri's allocation of treasury funds are viewed by the police as two central victories of democratization.

For Polri, "fiscal reform" has been narrowly interpreted to mean the single task of increasing the institutional budget. As Table 2 shows, Polri has largely been successful in this task.

Table 2: Department of Defense/Polri Budget 2001-2011 (trillions of rupiah) ${ }^{5 \tilde{5}}$

\begin{tabular}{|l|c|c|c|c|c|c|}
\hline Year & $\mathbf{2 0 0 1}$ & $\mathbf{2 0 0 2}$ & $\mathbf{2 0 0 3}$ & $\mathbf{2 0 0 4}$ & $\mathbf{2 0 0 5}$ & $\mathbf{2 0 0 6}$ \\
\hline Polri & 5,3 & 5,5 & 6,4 & 8 & 12 & 17 \\
\hline MOD $^{56}$ & 7,864 & 14,308 & 19,876 & 21,712 & 20,829 & 23,923 \\
\hline
\end{tabular}

\begin{tabular}{|l|c|c|c|c|c|}
\hline Year (cont.) & $\mathbf{2 0 0 7}$ & $\mathbf{2 0 0 8}$ & $\mathbf{2 0 0 9}$ & $\mathbf{2 0 1 0}$ & $\mathbf{2 0 1 1}$ \\
\hline Polri & 22 & 23 & 25.7 & 29 & 39.78 \\
\hline MOD $^{56}$ & 30,611 & 31,349 & 34,333 & 42,392 & 49,984 \\
\hline
\end{tabular}

Polri's budget has increased by approximately 3,500 percent since the transition to democracy. The defense budget has seen a slightly larger increase of 4,200 percent, however, this sum covers the defense administration, the army, the navy, and the air force, all of which have significantly higher procurement costs than do the police.

Despite these gains, Polri representatives argue that the deficiency in state funds is undermining police professionalism and causing officers to fund raise for themselves to cover operational costs. This central idea has dominated public thinking on the issue of police financing for decades. The organization of the off-budget economy will be explored in the second part of this section. This first subsection asks whether, in fact, Polri's budget is deficient, and, if so, whether that deficiency is calculable. Questions

\footnotetext{
${ }^{54}$ This is in comparison with other post-authoritarian police reform efforts, where reform is determined by political heads or bureaucratic leadership. Mercedes S. Hinton, The State on the Streets: Police and Politics in Argentina and Brazil (Boulder, CO, and London: Lynne Rienner, 2006).

${ }^{55}$ Figures have been compiled from newspaper articles reporting the annual budget. As a result, they may be imprecise to the hundreds of thousands. Due to a lack of clear reporting, figures for Polri have been compiled from multiple news sources. Figures for TNI have been compiled from the Stockholm International Peace Research Institute (SIPRI), "SIPRI Military Expenditure Database," http://www.sipri.org/research/armaments/milex milex_database, accessed August 7, 2013

${ }^{56}$ The Ministry of Defense budget includes departmental costs as well as all funding for TNI's three branches: army, navy, and air force.
} 
having to do with institutional financing are not easily answered in this case. Though they are public documents, police audits are not readily available, nor are they attentive to the structural and cultural causes of fiscal discrepancies. There is little institutional data. This makes interviews insufficient as sources of information, as officers are unable to articulate the wider fiscal structure in which they work. This section relies principally on three sources of data: (1) a report by the University of Indonesia's economic and social research institute, LPEM (Lembaga Penyelidikan Ekonomi dan Masyarakat), concerning police finances that was commissioned in 2002 by Partnership for Governance; ${ }^{57}$ (2) a 2007 police "Institutional Transformation Project" implemented by the International Criminal Investigative Training Assistance Program (ICITAP), ${ }^{58}$ and (3) my own interviews with officers conducted between 200712. The LPEM-UI report highlighted a number of key problems concerning the organization, prioritization, and transfer of police public monies, which I will outline here. In 2004, a year after the LPEM-UI report was released, treasury made changes to the distribution and transfer of those monies on top of the budget increase Polri received that year. These changes should combine to produce greater liquidity in the police institution, however, my own work and the ICITAP report suggests that there are continuing problems with the request and circulation of treasury funds.

Firstly, the LPEM-UI report highlighted problems in the way the 2002 Polri budget was prioritized. It found that a full 25 percent of the police budget went to Mabes Polri and only 7 percent to the territorial apparatus. Moreover, of the total budget amount, salaries, infrastructure, and administration made up 90 percent of Polri spending. The LPEM-UI report implied that the disproportionate amount of funds channeled to police headquarters rather than the other stations, and to staffing over operational needs, had its roots in the centralized decision-making structure that differentiates the institution from civilian bureaucracy. Polri, like the military, is proud to be a "national" institution, and this pyramid structure was mirrored in its financial arrangements. When Polri became independent in 1999, Mabes replicated the selfsame militarized structure that had so disadvantaged the institution by enacting a centralized budgetary system that placed all the decision-making power in the hands of the Department of Planning and Development (Derenbang) at Polri headquarters. Not only did this structure fundamentally pervert the way that funding was allocated, but it meant that information about the budget was concentrated in the center. The LPEM-UI research showed that in 2002, 65 percent of polres (subdistrict station) officers and 85 percent of polsek (mayoral station) officers had never seen their allocated budget and had no idea how much they were allocated that year. Staff signed for allocations that they did not get. The report argued that the lack of transparency around budget allocations meant that Polri's top officials had considerable power and opportunity to change and skim from the formal budget.

\footnotetext{
5. Lembaga Penyelidikan Ekonomi dan Masyarakat Fakultas Ekonomi Universitas Indonesia, "Financial Mapping: Reformasi Berkelanjutan Institusi Polri Bidang Manajemen Keuangan dan Anggaran Laporan Tahap Akhir," Markas Besar Kepolisian Republik Indonesia dan Kemitraan Bagi Pembaharuan Tata Pemerintahan, Jakarta, 2003.

${ }^{58}$ Indonesian National Police, US Department of State, US Department of Justice, and International Criminal Justice Investigative Training Assistance Program (ICITAP), Blueprint for Strengthening Polres and Polsek (Jakarta: ICITAP, 2007).
} 
Moreover, the new 1999 budgetary system was tiered so that financial transfers would flow down through every level of the command before reaching the requesting station. Unsurprisingly, this initial system saw significant pilferage at every level. When LPEM asked officers to estimate how much they thought was missing of their budget, staff at the provincial level stations guessed 15 percent, at the district level, 45 percent. The subdistrict police stations reckoned the discrepancy between their actual funds and the funds that they received to be around 54 percent.

This hierarchical system of financing the command ensured that transfers were not only filched as they moved through the system, but, crucially, that they moved through Polri at a torpid pace. LPEM-UI's data estimated that transfers (not just of money but also of petrol and electricity subsidies) from Derenbang at Mabes to the distributing arm of the Polda took, on average, three to five weeks, and then an additional few weeks to get to the polres and then into the polsek. The report found that funding transfers proposed at the beginning of the financial year arrived in March or April, and those applied for in the last quarter of the financial year didn't arrive at all. While district and subdistrict-level stations experienced a deficiency in funds, congestion in the transfer system meant that up to 40 percent of Polri's budget banked up at Mabes and the provincial level stations, leading to a convulsion of crash spending in the last half of the financial year.

In 2004, this trickle-down transfer system was replaced with a decentralized system that saw budgetary allocations transferred directly from provincial level treasury offices to district police stations. District police stations then transfer monies to the subdistrict level. This has drastically increased the political clout of the district police chief. In some parts of Jakarta, the district station makes monthly transfers, a schedule that appears to have increased their liquidity, although subdistrict police chiefs stationed in other parts of the country complain that "the polres is eating up all the money." ${ }^{59}$ In one subdistrict station I visited, the chief of police said that two million rupiah of their monthly allocation was deducted by the district station to contribute to a "guest" fund. ${ }^{60}$ The 2007 ICITAP report surveyed all stations under the regional commands in Bali, East Java, and South Sulawesi. Its findings spotlighted the same issues of fiscal bottlenecks and budgetary misappropriations as highlighted by LPEM-UI. In ICITAP's interviews, many officers at the polsek level reported signing budget dispersal forms and not receiving the stipulated funds, or, sometimes, receiving no funds at all. Officers estimated that they were operating on less than half of their allocated funds.

The new system has not brought significant change to Polri's budgetary priorities. Indeed, in 2007, Polri only spent Rp 211 billion (US\$24 million) of the Rp 18 trillion (US $\$ 2$ billion) of their budget on actual law enforcement, or "operational" activities." In a subdistrict station I surveyed in West Jakarta, the head of criminal investigations (reserse) argued that his budget was only enough to cover the costs of six investigations per year. "I get around a hundred cases per month. Should I just do all six cases in January and then take a holiday until December?" asked the department head. ${ }^{62}$ The

\footnotetext{
${ }^{59}$ Sectoral Police Chief, Interview with the author, Jakarta, April 6, 2007.

${ }^{60}$ Sectoral Police Chief, Interview with the author, Jakarta, September 24, 2012.

61 “Anggaran Polri Tak Rasional: Imbasnya Ditanggung Rakyat," Kompas, January 15, 2008.

${ }^{62}$ Mid-ranking police officer, interview with the author, Jakarta, January 21, 2012.
} 
situation appears to be worse in the regions distant from Jakarta. In the dozens of subdistrict stations surveyed by ICITAP in Bali, East Java, and South Sulawesi, operational budgets were nil.

The unpredictability and inadequacy of funds meant that officers in both the 2002 and 2007 surveys claimed they had chosen to carry out their duties and activities first and receive the tardy leftovers of proposed reimbursements later. To do operational work, officers said they were forced to fund raise. The LPEM-UI report divides offbudget funds into three main sources: parmin, or criminal sources; parmas, or "community" sources; and parman, funds from businesspeople or private enterprise. ${ }^{63}$ Of the three categories of off-budget funding, the LPEM-UI report observed that:

... the role of the ... parman is given highest priority for the acquisition of supporting funds, from the perspective of both size and frequency ... The tendency to use the contributions [jasa] of parman is not just at the subdistrict level but also at every level of the command system, starting from district and provincial stations up to Mabes Polri. ${ }^{64}$

Parman gift-giving foots the bill for police operations, for equipment and infrastructure, and for the cost of transportation, including the purchase and maintenance of vehicles and motorbikes. The report noted that parman also involve gifts of hibah tanah (land endowments), including buildings, and these funds provide for their maintenance or renovation. The report suggested that, contrary to police statements, off-budget revenue-raising means that officers had little use for the government reimbursements when they turned up. This meant that reimbursements were considered "free money," to be used at the discretion of the summoning officer.

The LPEM-UI report wanted to give a sense of the parman economy's scale, and so interviewers asked officers at every level of the police command their level of dependence on off-budget financing. Those at the provincial and district level stations estimated that $60-70$ percent of their budget came from parman sources. ${ }^{65}$ At the subdistrict stations, the figures were reckoned at over 95 percent. Broken down by station unit, figures were just as dramatic. The patrol unit (samapta) put the number somewhere between 80 and 90 percent, and, for criminal investigations, the figure was 99 percent.

At the same time, the researchers asked officers to write mock, aspirational budgets that would fulfill their operational needs. Officers faltered at the task, unable to come up with line items beyond snacks and petrol. ICITAP's 2007 report noted that stations it surveyed did not collect or archive basic institutional data on budgets, workloads, operations, staffing, or local security needs. Without such categories, the report's

\footnotetext{
${ }^{63}$ These are not hegemonic terms, and although most police officers recognize the acronyms, most would not use these forms of categorization. This typology also makes it unclear where some of the key enterprises of the police off-budget economy are situated in the scheme. For instance, selling Polri's subsidized fuel allowance is a major economy for Polri, as it was for the military, but how might this "gray" area trade be categorized?

${ }^{64}$ LPEM-UI, "Financial Mapping," p. 15.

${ }^{65}$ Ibid., Appendix 14.
} 
authors observed, stations cannot feasibly calculate how much money they would actually need to operate in a given year. ${ }^{60}$

What this suggests is that stations are not rational institutions, deftly managing their treasury and off-budget funds to meet working needs. Stations are unable to identify what an institutional need is, let alone to possess the capacity and political will to calculate their needs and seek funding for them. This means that the parman economy is not a modest stopgap in an inefficient, developing-world fiscal system. Rather, the combination of willful neglect and maladministration has structured an institutional dependence on the parman gift economy as the single most important, and least accountable, revenue source at all levels of the territorial command. In the practical, everyday lives of Indonesia's 380,000 -plus police officers, ${ }^{67}$ there is no economy outside of the off-budget economy. Of the different ways and means of illicit revenue-raising available to officers, exacting a "donation" from Indonesia's vulnerable, pariah, capitalist class is the most predictable, flexible, untraceable, and socially prized method of them all.

\section{The Parman Economy}

Such fantastical sums of money, capital, and resources form a vast interior current moving through the police institution, animating its everyday reasoning, its geographies, its stratagems, and its institutional considerations. The parman economy funds individual events, distinct posts, and units or notable officers. The parman economy underwrites choice drug and gambling busts, anti-terror exercises, community policing events, and intelligence gathering. Ethnic Chinese money also sponsors institution-building and knowledge-based exercises, such as seminars, meetings to draft model legislation, and networking events. A monthly stipend comes attached to individual posts and departmental units of certain authority, such as criminal research or intelligence, and to stations that guard Indonesia's ports, borders, gated residences, and industrial parks. Capital flows can also be invested in individuals, as a gifted stipend that notable officers receive for the duration of their careers.

Parman dividends are not subject to the moral constraints that govern the distribution of public revenue, which is accumulated and then redistributed. Rather, every unit, station, and department within Polri "works on its own, as if it were its own company." ${ }^{\prime 68}$ In a station, a resource deficient area (known as kering, or dry), such as education, cannot requisition funds from a resource rich unit (known as basah, or wet), such as criminal investigations. This means that parman monies pool in certain departments and units, leaving others depleted. Among Polri's ranks, talking about money, or the lack of it, is taboo. Station or unit heads delegate assignments without allocating funds. Monetary transfers arrive in sums much less than expected. For an

\footnotetext{
${ }^{66}$ Interview with the author, Jakarta, February 13, 2007.

${ }^{67}$ Dani Permana, "Jenderal Timur Pradopo: Personil Polri 387,470 Orang," Tribunnews.com, January 17, 2012, http: / / www.tribunnews.com / nasional / 2012/01/17/ jenderal-timur-pradopo-personil-polri387.470-orang, accessed September 6, 2013.

${ }^{68}$ Police general, interview with the author, Jakarta, November 6, 2006.
} 
officer schooled in the discursive decorum of Polri, it is unthinkable to raise this matter institutionally. The taboo against discussing money further atomizes the off-budget economy so that even the collective fund-raising of units and departments threatens to devolve further to individuals and factions. There is substantial capital, social and material, to be gained from the money taboo. The officer who courted the funds has autonomy over its spoils. "We don't have to be responsible for it, unlike the APBN," and therefore, the money is "easy come, easy go." ${ }^{69}$

Juniors who refrain from soliciting money vertically are identified as ikhlas; it shows they are prepared to sacrifice for the institution, stressed one middle-ranking criminal investigations (reskrim) officer. ${ }^{70}$ More importantly, displays of fiscal potency cloak officers in enigma and prowess, the production of which is a central tactic to gaining status within the force. Officers are almost singularly preoccupied with interpreting and decoding the actions and insinuations of their colleagues. It's what they speculate on well into the night. Allusions to an ethnic-Chinese benefactor inspire awe and envy. ${ }^{71}$ "Fulfilling my duties as an officer without asking for money is what makes me remarkable [hebatnya saya] in the eyes of authority," added the officer. ${ }^{72}$

The parman economy is also deeply and intractably gendered. Revenue-raising is an important part of an officer's responsibilities. Attracting parman funds is not always merely a matter of rank or position. It's about mobility and sociality. An officer must circulate and associate (gaul) in important sub-state spaces, particularly nightclubs, golf courses, and particular karaoke bars. These are principally masculine spaces where relationships emerge through the mutual transgression of laws and norms: the "gift" of female escorts or the sharing of illicit substances. Female police officers, unwelcome in this unique realm, are shut out from this economy. Their inability or reluctance to perform this kind of corrupted sociability as a way of establishing fiscal viability, or mampu secara operasional (the state of being "operationally capable"), is what keeps the Polri top brass exclusively male. ${ }^{73}$

From Polri's perspective, meeting and maintaining a patron is considered by police superiors as an integral rite of passage and, as a rising officer circulates through postings and departments, he is expected to establish contacts and patronage networks that will serve the institution in the future. Entertaining good relations with ethnic Chinese backers is seen as so integral to the well-being of the institution that the social and professional life of an ambitious officer is organized around the bureaucratic itinerary of ethnic Chinese business figures. Postings in Jakarta, Medan, and Surabaya link officers to certain parman who will advance their careers. Because of this, the parman economy creates stark disparities among different geographic areas within the command, between territories dense with parman and those without. For instance, the LPEM-UI survey found that officers trained at AKPOL (Akademi Kepolisian, the police academy) clustered in areas rich in private capital, while graduates of the less prestigious SPN (Sekolah Polisi Negara, the National Police School) were stationed

\footnotetext{
${ }^{69}$ Mid-ranking police officer, interview with the author, Jakarta, March 7, 2007.

${ }^{70}$ Ibid.

${ }^{71}$ Mid-ranking police officer, interview with the author, Jakarta, September 26, 2011.

${ }^{72}$ Ibid.

${ }^{73}$ Mid-ranking police officer, interview with the author, November 10, 2006.
} 
where there was minimal commercial activity. ${ }^{74}$ The parman economy is also critical for officers who wish to pursue higher education, such as the degree program at the Police Higher Education Academcy (Perguruan Tinggi Ilmu Kepolisian, PTIK), and the senior management courses at SESPIM (Sekolah Staf Pimpinan, School for Staff and Police Managers). At PTIK, one junior officer told me that he and every one of his classmates had their education sponsored by an ethnic Chinese. ${ }^{75}$

Access to liquidity brings greater mobility within the police institution. This is not just because officers supplement their salaries from the parman economy. Police postings, rotations, and promotions are often determined by cash bribes. Ethnic Chinese patrons supply the capital integral to the bidding and counter-bidding process required of police officers to circulate upwards into more lucrative or prestigious positions. Unsurprisingly, the parman economy affords ethnic Chinese capitalists significant sway over the promotions and postings of officers. At PTIK, young graduates solicited their next posting from ethnic Chinese capitalists who had the ear of those in the upper echelons. ${ }^{76} \mathrm{~A}$ former senior police commissioner with the police explained:

You can't be promoted or rotated without the ethnic Chinese [golongan Cina]. They have an incredible influence on postings. There are bribes he [the patron] must pay, and he'll also give facilities ... To become a kapolsek [subdistrict police head], you must have a patron. We don't have a merit system. This is why we have this system. ${ }^{77}$

Officers defend this kind of long-term benefaction, arguing that the predictability and stability of parman funds allow them to stay focused on "policing" rather than being trapped in the pursuit of less palatable, more unstable funds from criminal, parmin sources.

Parman funds also enable an officer to build a strategic network of support up and down the Polri hierarchy, by regifting the spoils of the parman economy to subordinates in exchange for loyalty. Such junior officers may be given cash bonuses for achieving policing goals, or introduced to a parman. By circulating the rewards of the parman economy, an officer is able to maintain discipline (disiplin), a sign of masculinized leadership at all levels of command. At the same time, parman funds help officers curry favor among their superiors by recirculating capital upwards as gifts or monthly payments. Visiting officers make up a third category of recipient. The gift economy for visiting officers is a substantial financial burden on local police. Guests must be supplied with petrol, escorts or "companions," drugs, nights out on the town, and cash envelopes (amplop) to see them safely on their journey. In one

\footnotetext{
${ }^{74}$ Also see Jacqui Baker, "Sibling Rivalry," Inside Indonesia, August-December 2008, http: / / www. insideindonesia.org/feature-editions / a-sibling-rivalry, accessed August 13, 2013.

${ }^{75}$ Junior-ranking officer, interview with the author, Jakarta, A pril 112007.

${ }^{76}$ Ibid.

${ }^{77}$ Retired Police General, interview with the author, Jakarta, November 16, 2006. It's important to note that human resources reform within Polri was, until 2007, a very important plank of institutional reform, precisely because of its critical link with the off-budget economy. Some reforms were implemented, but they have stopped short of ending the role of parman funds in rotations and promotions.
} 
subdistrict station I surveyed, the monthly "guest" fund was 40 million rupiah (about US $\$ 4,500){ }^{78}$

Polri's parman economy operates in the gray zone between licit and illicit, legitimate and illegitimate, individual and structural. By marrying the promise of individual wealth accumulation and career advancement with institutional needs, it occupies moral terrain within the state as illicit, but legitimate. It does this in ways that are complex and often asymmetrical, but morally defensible by its beneficiaries and according to the institutional structure in which they operate. As long as officers continue to negotiate an acceptable balance between personal wealth accumulation, the outward performance of legal and security functions, and the institution's important internal political relations of illicit exchange and transaction, which determine individual officers' advancement and influence, the parman economy will continue to form the basis of Polri's fiscal system.

\section{The Democratic See-Saw}

The fall of the New Order in 1998 was marked by unprecedented rioting that targeted ethnic Chinese enterprises. In their personal recollections of those riots, some ethnic Chinese capitalists reported having been protected by their military connections. Others had the bitter experience of being abandoned by their military ally or pressed for more gifts in their time of need. Either way, the very fact of such violence specifically directed against ethnic Chinese and the suspicion that military elements stoked the forces behind that violence dealt a staggering blow to the Chinese trust in the soldiers as their protectors.

Ethnic Chinese disenchantment with the military converged with wider political and structural reforms-such as ABRI's disbandment and the military's withdrawal from an explicit political role-to curb the military's power. The 2004 TNI law specified that military businesses would be subject to government takeover by 2009 . This process, however, has been subject to subversion and delay, allowing the military to sell off valuable assets. ${ }^{79}$

In addition to the military's declining political influence, early in Indonesia's transition to democracy its joint enterprises were showing considerable signs of decay. Ernst and Young's 2001 audit of YKEP showed a capital structure on the verge of collapse from years of embezzlement, the Asian financial crisis, and the emergence of a more competitive market. ${ }^{80}$ In 2000 , YKEP returned a net loss of Rp 8.21 billion (US $\$ 915$ million) and total contributions to the defense budget from the yayasan-cooperative economy slumped to 1 percent in 2000 and 0.7 percent in $2001 .^{81}$ Although generals occupied strategic seats on the board of YKEP, either they had little operational influence or the foundation was listed as a non-cash partner in joint ventures. Indonesian Corruption Watch concluded from the Ernst and Young audit that YKEP's

\footnotetext{
${ }^{78}$ Sectoral Police Chief, interview with the author, Jakarta, September 24, 2012.

${ }^{79}$ Mietzner, "Soldiers, Parties, and Bureaucrats," p. 223.

${ }^{80}$ Ibid. See also Human Rights Watch, "Too High a Price," p. 15.

${ }^{81}$ Human Rights Watch, "Too High a Price," p. 15.
} 
various investments with Oei-Guo, in particular, did not favor military interests and that the generals had little bargaining power vis-à-vis their ethnic Chinese partners. Delays in regulating the foundations gave the generals a profitable exit. In 2005, Major General Kiki Syahnakri, a representative of YKEP who joined the bank as a commissioner in 2000, facilitated the sale of TNI's falling stake in Bank Griya Yatra for Rp 151 billion (US\$16 million) without first seeking state permission. ${ }^{82}$ Oei- and Guoowned companies ate up YKEP's share in PT JIHD, reducing military holdings in the company to small personal claims.

The rise of Oei and Guo and the demise of YKEP tallies well with Chua's argument that capital in Indonesia has been liberated from the politico-bureaucratic oligarchy since the fall of Suharto. However, Indonesia's unique democratization, with its attendant processes of decentralization and demilitarization, has fragmented political power and emboldened a new, variegated class of political elites who demand rites of tribute and reward similar to the exchanges that typified the New Order ${ }^{83}$ The Indonesian National Police has been chief among this new, competing predatory class. The police's rise to power has been accelerated by reformasi's perverse preoccupation with legality (rather than the implementation of rule of law). Polri's power to distinguish between the illegal and the legal in an age when law has become the terrain upon which contemporary political and economic battles are fought has impelled capital's stampede to claim a police "friend." Thus, the distinct characteristics of Indonesian democratization coupled with security sector reform have unintentionally reorganized, rather than democratized, the state's coercive apparatus, and given teeth to a repressed younger sibling now looking to capitalize on its position after years of fiscal subordination. In this way, ethnic Chinese alliances with the military via joint enterprises have given way to an atomized and individualistic, but no less structured, partnership with the police.

How are these new relationships between capital and police initiated, organized, and displayed? As it was under the New Order, the performance of an alliance is critical to its effect. The protective benefits of a police ally are only activated with an audience. If in Suharto's time affixing a military general to the board of directors was integral to the theater of protection, in the democratic era, capital's turn to the police has been channelled through new citizenship activities now permitted for the ethnic Chinese community. After 1998, religious organizations, civic NGOs, and new media, have proliferated "like mushrooms after spring rain." ${ }^{84}$ This has included every type of organization and structure, from powerful national organizations such as INTI (Perhimpunan Indonesia Keturunan Tionghoa, the Association of Indonesians of Ethnic Chinese Descent), to local-level mini-parliaments, clan (marga) associations,

\footnotetext{
82 "Penjualan Saham TNI di Artha Graha Disorot," Bali Post, September 9, 2005, http: / / www.balipost. co.id/balipostcetak/2005/9/9/n3.htm, accessed August 13, 2013.

${ }^{83}$ Edward Aspinall, "The Irony of Success," Journal of Democracy 21,2 (2010): 20-34. Edward Aspinall, "A Nation in Fragments: Patronage and Neoliberalism in Contemporary Indonesia," Critical Asian Studies 45,1 (2013): 27-54. See also, Vedi Hadiz, "Decentralization and Democracy in Indonesia," Development and Change 35,4 (2004): 697-98.

${ }^{84}$ Mary Somers Heidhues, "Ethnic Chinese Voluntary and Involuntary Associations in Indonesia," in Voluntary Organizations in the Ethnic Chinese Diaspora, ed. Khun Eng Kuah-Pearce and Evelyn Hu-Dehart (Hong Kong: Hong Kong University Press, 2006), p. 89.
} 
volunteer fire bridges, sporting groups, and charities established by a single conglomerate head, such as Guo's own Tzu Chi or Oei's Griya Yatra Peduli (Griya Yatra Cares). The bona fide charity work of conglomerate charity organizations rotates carefully among the constituencies and interest groups of new political elites, including the national police.

These activities are reported in ethnic Chinese media, which has experienced a parallel explosion since the fall of the New Order. ${ }^{85}$ In 2008, Ted Siong's International Daily News (Guo Ji Ri Bao) captured the Mandarin-speaking business elite with national distribution and a pro-China stance, after a rival paper, the pro-Taiwan Universal Daily News, folded. International Daily News's sister publication is National News, a daily, subscription-only broadsheet published in Bahasa. With a daily circulation of around fifty thousand, National News is sponsored by a number of ethnic Chinese capitalists who distribute the paper among their employees and in Jakarta police stations. Sponsors include Tony Oei's Bank Griya Yatra, Eka Cipta Widjaya's Sinarmas, Alex Guo's Raya Sedayu Group, Prajogo Pangestu's Barito Pacific, and Trihatma Guo Haliman's giant real estate enterprise Agung Podomoro. The newspaper also receives substantial contributions from regionally based corporations such as Maspion, Olagafood, and GRC Board (West Java). The Jambi ethnic Chinese community is also an especially strong financial backer of the paper.

The paper is edited by Mochtar Siahaan and Lee. The former, Lee explains, is a former journalist who has strong connections with the police. According to Lee, Ted Siong designed National News specifically to encourage relations between police and the ethnic Chinese business community. "We wanted to present a non-biased image of the police and give voice to them as they are not normally heard," observed Lee. ${ }^{86}$ True to Siong's aim, a number of pages in each issue of National News are dedicated exclusively to Polri. Typically, page five, entitled "Police Line," gives a positive spin to police operations and policies. A side column called "Police on My Mind" features attractive youth and their satisfied opinions about police conduct and the reform process. On page two, the National News presents its "Man of Today," a Polri officer of kapolres rank or above (see images, next page). The article details the officer's policing principles and past achievements, and specifies his telephone numbers. An officer's entire CV is published alongside photos of the officer's family and children.

The middle pages of the broadsheet consist of a high-color insert, picturing recent activities by ethnic Chinese social and religious organizations in a section entitled "Indonesia: I am in Love." Articles cover the opening of new Buddhist and Mandarin schools, corporate events, the elections within regional marga societies, and recent meetings with important politicians and police and military generals. Many ethnic Chinese social organizations undertake committed charity work, such as blood drives, donations of sembako (the nine basic necessities for living), health-check (wellness) drives, and fund-raising for Islamic schools, and invite local police to witness or present gifts along with their ethnic Chinese corporate sponsors. Other events focus explicitly on police policies, such as supporting anti-narcotics events.

\footnotetext{
${ }^{85}$ Suryadinata, The Culture of the Ethnic Chinese.

${ }^{86}$ Lee, interview with the author, Jakarta, A pril 9, 2007.
} 

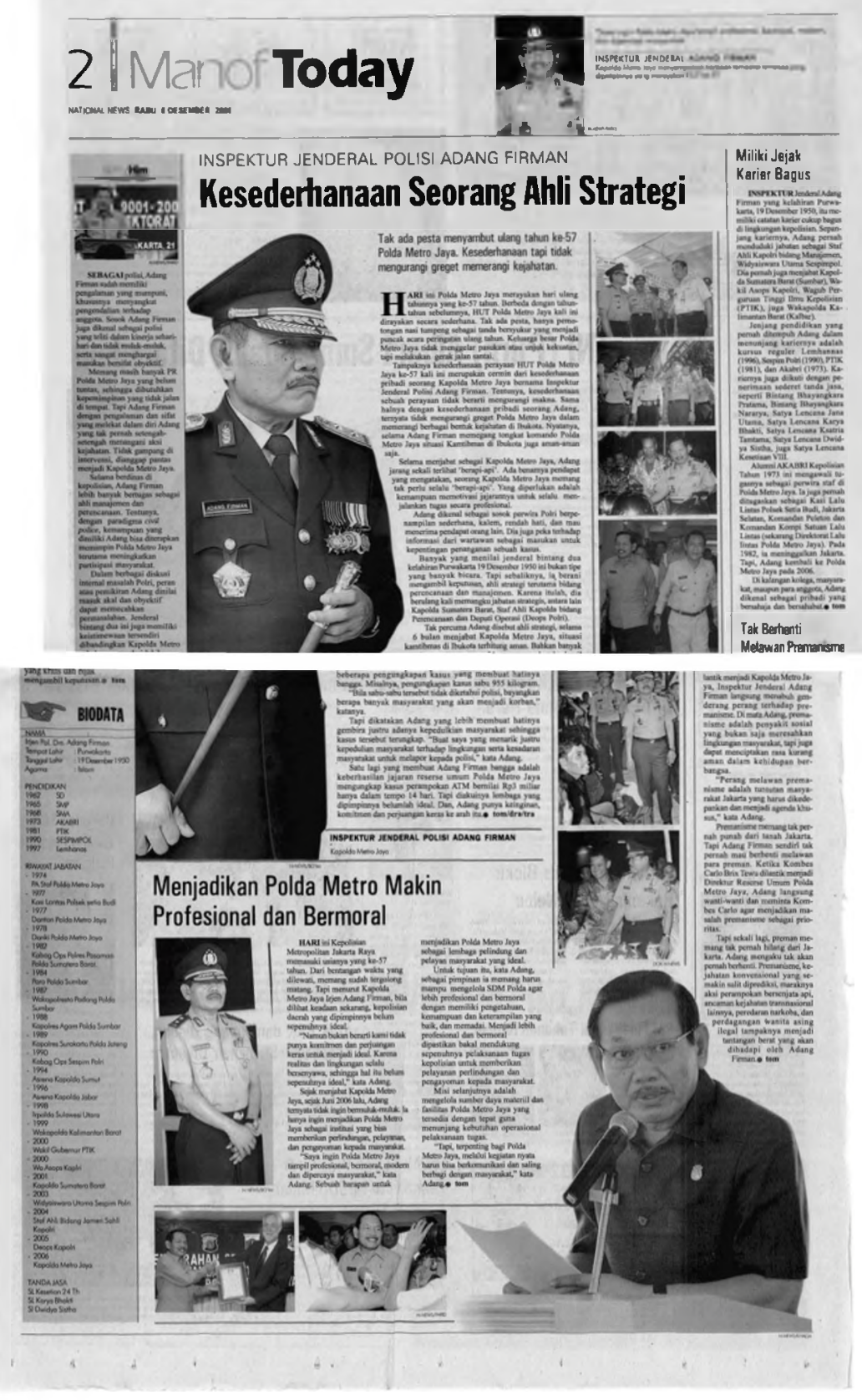

National New's page 2 feature, "Man of Today," December 6, 2006, which spotlights Irjen. Adang Firman, Kapolda Metro Jaya. The article is titled "The Simplicity of a Strategist." On the left-hand side is the general's resume and biography, and, on the right, a description of his career path. The subtitle says, "Making Polda Metro More Professional and Moral." ${ }^{87}$

87 "Making Polda More Professional and Moral," National News, December 6, 2006, p. 2. 
All reports of such events are accompanied by large color photographs with extended captions, printed in a bold font, naming key persons of the organization and their respective positions.

This kind of reporting is understood by other capitalists as "a show of force," or a type of "theater" (sandiwara) ${ }^{88} \mathrm{New}$ ethnic Chinese media and civil society groups have provided the means for capital to seek protection, establish strategic friendships (cari hubungan) with the police elite, and show them off (cari imaj). ${ }^{89}$ One ethnic Chinese businessman observed, "under Suharto, the one thing we could do was give contributions [sumbang]. The way of the ethnic Chinese is still the way of the New Order, that is, sumbang." 90

Off-budget funding continues to shape the life of state institutions in postauthoritarian Indonesia. Here, I have shown how the power dynamics of democratization in the security sector have been echoed in the subterranean, illicit world of state off-budget financing. Ethnic Chinese capital, once earmarked exclusively for the military, has realigned itself with the police as that institution's political clout has risen. However, where structural alliances between capital and the military once took the ironclad form of a joint alliance, democratization has created the parman economy, a series of fragmented and atomized, but no less systematic, relationships that are even less subject to scrutiny. Without substantive fiscal and institutional reform to the police institution, ethnic Chinese funds will continue to finance Polri's complex, political life.

In the post-authoritarian era, the police are an economic actor under transformation. As the police's star rises, its entrepreneurial impulse strengthens. "Business, business, business, it's all about having a business," a grinning police general told me. ${ }^{91}$ Most officers I know have established small- and medium-scale personal businesses in the primary commodities and service sectors. They argue that it provides them with a flow of capital to support their political careers within the police. At the regional and district level, police maintain businesses that operate in total obscurity. ${ }^{92}$ Most recently, a low-ranking officer stationed in Papua has been investigated for illegal logging operations managed thorough two companies registered in his name. These companies saw over one trillion rupiah pass through their accounts over a five-year period. Will the emergence of personal police businesses eventually evolve into joint enterprises with ethnic-Chinese, who dominate private commerce?

More traditional forms of alliance and display have also emerged in this transformation of the police. Retired police generals are beginning to appear on the boards of known patrons of the police, including appointments to Nagaria's

\footnotetext{
Ethnic Chinese business owner, interview with the author, Jakarta, March 3, 2007.

${ }^{89}$ Ibid.

${ }^{90}$ Ethnic Chinese business owner, interview with the author, Jakarta, April 27, 2007.

${ }^{91}$ Police General, interview with the author, Jakarta, November 17, 2006.

${ }^{\prime \prime}$ Retired Police General, interview with the author, Jakarta, April 31, 2008. Also, Police General, interview with the author, Jakarta, January 13, 2006.
} 
Summarecon, Sjamsul Nursalim's Gajah Tunggal, and Hari Tanoe's Bhakti Investama. ${ }^{93}$ Similarly, at the regional and local level, pensioned police officers are filling the boards of medium-size enterprises. ${ }^{94}$ Echoing this trend, police, as army generals did under the New Order, have also begun to infiltrate pribumi ("native" Indonesian) and state enterprises ${ }^{95}$ High-ranking generals have taken up positions at Tommy Suharto's Humpuss and in state enterprises, such as PT Timah (the state's tin company operating out of Bangka Belitung) and PT Perkebunan Nusantara V (the state agricultural company specializing in fertilizer and now biodiesel). Whether these appointments represent the tendrils of the kind and scale of the army's economic empire-building under the New Order remains to be seen.

\section{Glossary}

\section{Police Stations by Rank, descending}

Markus Besar (MABES) Polisi - National Police Headquarters

Polisi Daerah (Polda) - Regional Police Station corresponding to provincial [propinsi] level government

Polisi Daerah (Polda) Metro Jaya - Jakarta Regional Police Station for DKI [Daerah Khusus Ibu Kota Raya] Jakarta

Polisi Resort (Polres) - District Police Station corresponding to district [kabupaten] level government

Polisi Sektoral (Polsek) - Subdistrict Police Station corresponding to subdistrict [kecamatan| level government

\section{Police Schools By Rank}

Sekolah Staf Pimpinan (SESPIM) - School for staff and police managers

Perguruan Tinggi Ilmu Kepolisian (PTIK) - Police Higher Education Academy

Akademi Kepolisian (AKPOL) - Police Academy

Sekolah Polisi Negara (SPN) - National Police School

\section{Police Positions by Rank}

Kepala Polri (Kapolri) - National Police Chief

\footnotetext{
${ }^{93}$ Since 2006, Snr. Com. Posma Lumban Tobing had held a commissioner position in a range of companies under Hary Tanoe's control. In that same year, former Kapolri Dibyo Widodo was also appointed to President Commissioner of Gadjah Tunggal. In 2009, Irjen Edi Darnadi was appointed at Summarecon.

${ }^{94}$ For instance, Irjen. (purn, retired) Logan Siahaan is the Independent Commissioner of Jakarta-based PT Asuransi Wanamekar Handayani, and former Kapolri Dibyo Widodo is President Commissioner of Jakarta property developer, PT Indonesia Prima Property and PT Panen Lestari Basuki.

${ }^{95}$ In 2008, Brigadier General Karyono entered PT PNV after a career in Inkopol (Induk kooperasi kepolisian, the police's parent cooperative) and Irjen. Polisi Drs. Insmerda Lebang joined the board of commissioners at PT Timah. After stepping down from his position as head of the police in 2008, General Sutanto was appointed by the president to lead Pertamina, a position formerly held by distinguished heads of the TNI. In 2009, Irjen. Rubani Pranoto joined PT Petrokimia Gresik.
} 
Wakil Kepala Polri (Wakapolri) - Deputy National Police Chief

Kepada Polisi Daerah (Kapolda) - Chief of the Regional Police

Kepala Polisi Resort (Kapolres) - Chief of the District Police

Kepala Polisi Sektoral (Kapolsek) - Chief of the Subdistrict Police

\section{Police Agencies}

Brigade Mobil (Brimob) - Mobile Brigade

Detasemen Khusus 88 (Densus 88) - Police Anti-terror squad

Inspektor Pengawasan Umum (Irwasum) - General Oversight Inspectorate

Kepolisian Negara Republik Indonesia (Polri) - National Indonesian Police

Reserse kriminal (reskrim) - Criminal investigations

Samapta - Patrol unit

\section{Government Institutions and Terms}

Angkatan Bersenjata Republik Indonesia (ABRI) - The Indonesian armed forces before TNI was reinstated

Anggaran Pendapatan dan Belanja Negara (ABPN) - State Budget

Anggaran Belanja Tambahan (ABT) - Additional Expenditure Budget

Badan Pengawas Keuangan (BPK) - Supreme Audit Agency

Badan Usaha Milik Negara (BUMN) - State Owned Company

Badan Urusan Logistik (Bulog) - Indonesian Bureau of Logistics (formerly Bidakari)

Komisi III - National Parliamentary Commission III for Law, Human Rights, and Security

Perusahan Energi Indonesia (Pertamina) - State Oil and Natural Gas Mining Company

Tentara Nasional Indonesia (TNI ) - Indonesian National Armed Forces

Yayasan Adhi Upaya - a foundation of the air force

Yayasan Bhumyamca - a foundation of the navy

Yayasan Brata Bhakti YBB - the largest national police foundation

Yayasan Kartika Eka Paksi (YKEP) - The largest army foundation during the New Order

PT Tri Usaha Bakti (PT Truba) - a holding company for YKEP

\section{Research Institutes}

ICITAP - International Criminal Investigative Training Program

LPEM-UI - Lembaga Penyelidikan Ekonomi dan Masyarakat, Universitas Indonesia University of Indonesia Institute for Economic and Social Research 